\title{
Improving the Number Sense Ability of Elementary School Students in Mathematics Learning
}

\author{
Yuniawatika \\ Elementary School Teacher Education \\ Universitas Negeri Malang \\ Malang, Indonesia \\ yuniawatika.fip@um.ac.id
}

\begin{abstract}
Numbers are one of the scopes of mathematics that has been familiar since childhood because numbers are everywhere. Numbers are close to everyday life because they can be found in many ways and are used in various fields. Understanding the concept of numbers correctly and correctly will have a significant impact on advanced mathematics. The concept of numbers can be mastered by students if the number sense ability develops in students. Number sense is related to flexible thinking about numbers. Number sense is an ability that plays a very important role in solving mathematical problems that can be developed through learning. In this case, PMRI is a learning that needs to be considered to improve the ability of students' number sense.
\end{abstract}

Keywords - number sense, mathematics learning, elementary school

\section{INTRODUCTION}

Mathematics is a very important material. This can be seen from the teaching of mathematics from the level of early childhood education to higher education. The importance of mathematics is learned because mathematics is one of the basic sciences used in daily life and plays a role in the advancement of science and technology. This is in accordance with the opinions expressed by Yuniawatika [1], namely mathematics has a connection with daily life both now and in the future so it is very important to be given in schools both at the primary, secondary and high levels.

Mathematics in elementary schools (SD) has three scopes of material or material for mathematics studies, including numbers, geometry and measurement, and data processing. The scope of mathematics is in line with the mathematics content standards based on the National Council of Teachers of Mathematics (NCTM), namely "Numbers and operations, algebra, geometry, measurement, data analysis, and probability" [2]. Numbers are part of the largest content of the scope of mathematics and mathematical content standards. This is in line with Walle's opinion [2] that numbers and operations are the largest content section for Pre-Kindergarten to 5th grade, and also an important part for grades 6-8 and decreasing in grades 9-12. Once the importance of numbers shown in international studies that measure the ability of students in math and science, namely TIMSS, in this study had a percentage of the total number of the greatest problems that is equal to $50 \%$ of the whole matter TIMSS [3].

The problem is learned early because it is the foundation for learning further mathematical materials. Because Numbers are mathematical concepts that underlie other branches of mathematical mathematics and are used in almost all branches of mathematics [4]. For example measurement of geometry requires numbers to represent it, the solution of an algebra requires numbers, and data processing requires sensitivity number. Thus a good mastery of the scope of the numbers for elementary school students, in particular, is very necessary because it can affect students 'mastery and proficiency in mathematics throughout his advanced concepts and to support the students' daily activities.

Considering the importance of numbers as described above, the numbers should need to get the main attention, especially in elementary school. A person's thinking skills or skills about numbers are called number sensitivity or number sense. According to Saleh [5], number sense means a person's sensitivity to numbers and their operations. This means that number sense is closely related to numbers and operations. Therefore, people who have a good number sense will make it easier to solve everyday problems in various situations because the numbers and calculations have an important role in everyday life.

Once the importance of number sense is not accompanied by facts that occur in the field. Many students have poor number sense. Putrawangsa [6] found that the level of sensitivity of elementary school students included in the invisible category, which is the lowest level of 4 levels, that is not yet visible, visible, revealed, and skilled. This is in line with the findings of Sari's research [7], namely that all research subjects in primary schools lack understanding regarding numbers and operations. This can be seen from all subjects in solving mathematical problems not understanding the relationship between the context of the problem and the necessary calculations, not having the awareness of some strategies, not being inclined to use efficient representations and/or methods, and not inclined to review data and results for sensibility. In addition to the results of research at the elementary level, it turns out that even junior high school students have a number sense that is not good enough can be seen from the research of Safitri et al. [8] found that all research subjects of seventh grade students at Surya Gemilang Tutoring Institute did not have a sufficiently good number sense regarding the relationships between numbers, number operations, relationships between number operations, and their properties so that all subjects were inflexible and focused. On the use of procedural calculations, they received at school when solving problems. In addition, there is a fact that the results of the TIMSS study in 2011 the percentage of Indonesian students on content numbers and operations have scored below the average. It turned out that the results were repeated in 2015, the score of Indonesian students on the number content was 24 of the 50 
international average scores, meaning that Indonesia was below the international average [9].

Based on some of the results of the study, it can be seen that the student's sense number is still not seen well in the Putrawangsa, Sari, Safitri et al research, as well as on the results of TIMSS. Thus it is necessary to find a solution to develop the number sense ability which is very impactful when studying advanced mathematics and daily activities. Given the importance of number sense influencing advanced mathematics and supporting daily activities, the number sense ability of students needs to be explored, trained, and developed in gradual learning starting from an early age, especially in elementary school. Based on this, the writer is motivated to study the alternative implementation of learning that can improve the ability of number sense, especially elementary students. The alternative learning that will be discussed is constructivism-based learning.

\section{NUMBER SENSE}

Number sense or number sensitivity is one of the most important concepts learned by children. According to Yang D. C, Reys R. E and Reys B. J [10], number sense is a complex process that involves many different components of numbers, which is the focus of research and discussion between mathematics educators and curriculum developers. According to Fennel and Landis [5], "number sense is a person's awareness and understanding of the numbers, relationships among numbers, importance, and the calculation by using mental math". This opinion is in line with Mohamed et al. [11] number sense can be described as good intuitions about numbers and their relationships. In addition, according to Gersten and Chard [12], it is written that the number sense is essentially a reference to a student's fluidity and flexibility with numbers. Based on four The opinion above can be seen that Number sense is not just counting which is the basis for basic work in numbers but more than that. number sense is a person's sensitivity about many components of numbers and relationships between numbers.

Number sense is very instrumental in developing mathematical abilities and helping in daily activities. According to Mohamed et al. [11] individuals with good number sense tend to exhibit the following characteristics when performing mental computations; sense-making approach, planning, and control, flexibility and appropriateness sense of reasonableness. This is in line with Burton's opinion [13] someone with a good number sense can use various ways and strategies to solve complex problems. This ability includes estimating, knowing the size of a number, being able to model a problem into a mathematical model, and being able to solve a problem with the right reasons. Thus, each individual needs to have number sense ability so that he can develop mathematical abilities and help in carrying out daily activities.

In the International Handbook of Mathematics Education: The NCTM document defines standards number sense about numbers that involves five integrated components: (1) number meaning, (2) number relation, (3) relative magnitude of numbers, (4) relative effect of operation on number, (5) meaningful referent for number and quantity [12]. Based on the above statement, the NCTM standard document defines the number sense as an intuition of numbers consisting of five important components. This component is in line with
Saleh's [5] opinion namely "number meaning, number magnitude, number relationship, number operations, number referents. " Each explanation is as follows [5]:

\section{1) Number Meaning}

Number meaning is related to the basic concept of numbers starting from the meaning of numbers, history of numbers, types of numbers, and properties of numbers. Number meaning is also related to the basic meaning of numbers. Students must understand and be able to see the meaning of a number such as association and interpretation of a number. For example, 0.25 can be interpreted as infractions, $2+3=3+2$ is defined as the commutative nature of the original number for the sum operation. In addition, students can understand integer story problems related to everyday life, students can understand FPB and KPK issues related to daily life, and so on.

\section{2) Number Magnitude (Quantity of a Number)}

Number magnitude gives the view that numbers are quantities, meaning numbers are things that can be measured and calculated. Understanding the magnitude of numbers and comparing them to other numbers or number magnitudes is very basic in number sense. In addition, sorting numbers are also included in the Number magnitude capability. For example, 7583 and 7912,5 and 9 occupy hundreds of positions so they can know that $7583<7912$.

\section{3) Number Relationship}

Number relationship is a relationship between numbers, including a number that can be represented in a different form. For example, 169 is the square of 13, then 21 is half of 42 and many more.

\section{4) Number Operations}

Number operations describe various mathematical calculations ranging from addition, subtraction, multiplication, division, division, to number factoring. The indicators of number operations include students can understand the operation of calculating correctly, students can work on number counting operations related to daily life, students can do count operations on regular fractions and fractions, students can estimate the results of count operations.

\section{5) Number referents (Reference Numbers)}

References owned by a certain number are included in the number referents. For example, privileges of zero numbers, privileges of the zero power of the identity of numbers 1, and so on. Students can determine the results of operating numbers with zeros (privileges of zero numbers), students can determine the results of zero-level operations (privileges of zero), and students can determine the results of the operation of rank number 1. From the example of the problem, it can be understood that any number when multiplied by 1 then results in 13 that is the number itself.

Unlike Saleh and NCTM, McIntosh et al [13] group four components of understanding sense number, namely:

\section{1) Understand the basic meaning of numbers and operations.}

This is the ability to understand number systems, place values, numerical patterns, four basic operations and various ways of representation. Students must know that numbers can be represented in more than one way, for example, 300 is equal to 3 groups of 100 . 


\section{2) Recognizing the relative and absolute magnitude of a number.}

This implies that children can recognize the relative and absolute size of numbers. For example, when students compare whole numbers, they must have a good sense of the value of the place and to know that $2.009>555$ because 2009 is more than a thousand and 555 is less than a thousand. In addition, when a fifth-grade student asked, "Do you live more or less than 1. 500 days?" They should know that the first year is 365 days, and 10 years had to live around 3,650 days

\section{3) Able to use the right benchmark.}

This means that an individual can use a benchmark (for example $1, \ldots, 100)$ to solve the problem correctly in different situations. For example, when children are asked to estimate the high flagpole, they know that the height of the flagpole is around double the height of their teacher, so the answer is around 3-4 m.

\section{4) Assess the fairness of results.}

This refers to the individual's ability to mentally applying estimation strategies for problems without using paper and pencil. Example, when estimating the distance of an area, students will use the information they know, such as distance from school to home is $6 \mathrm{~km}$, and the distance is half the market distance to school, means the distance from home to the market is $3 \mathrm{~km}$.

Based on the number of components in the above sense can be seen that these components have the same meaning that number, number magnitude, number referents, and also there are estimates therein.

\section{NUMBER POSITION IN 2013 CURRICULUM}

Mathematical basic competencies the scope of numbers in the 2013 curriculum contained in Permendikbud No. 24 of 2016 can be stated as follows:

\section{TABLE I. MATHEMATICAL BASIC COMPETENCIES}

\begin{tabular}{|c|c|c|}
\hline \multicolumn{3}{|c|}{ 1st Grade } \\
\hline Basic Competence (Knowledge) & & Basic Competence (Skill) \\
\hline $\begin{array}{l}3.1 \text { Describes the meaning of } \\
\text { chopped numbers up to } 99 \text { as } \\
\text { many members of a collection } \\
\text { of objects }\end{array}$ & 4.1 & $\begin{array}{l}\text { Presents chopped numbers up } \\
\text { to } 99 \text { which correspond to } \\
\text { many members of the set of } \\
\text { objects presented }\end{array}$ \\
\hline $\begin{array}{l}3.2 \text { Explain numbers up to two } \\
\text { numbers and the value of the } \\
\text { place of the number symbol } \\
\text { using a collection of concrete } \\
\text { objects and how to read them }\end{array}$ & 4.2 & $\begin{array}{l}\text { Write a symbol number up to } \\
\text { two numbers that state many } \\
\text { members of a collection of } \\
\text { objects with the idea of place } \\
\text { value }\end{array}$ \\
\hline $\begin{array}{l}3.3 \text { Compare two numbers } \\
\text { up to two numbers using a } \\
\text { collection of concrete objects }\end{array}$ & & $\begin{array}{l}\text { Sorting numbers - numbers } \\
\text { up to two numbers from the } \\
\text { smallest number to the largest } \\
\text { number or vice versa by using } \\
\text { a collection of concrete } \\
\text { objects }\end{array}$ \\
\hline $\begin{array}{l}\text { 3.4 Explain and carry out the } \\
\text { addition and subtraction of } \\
\text { numbers involving numbers } \\
\text { up to } 99 \text { in daily life and } \\
\text { linking addition and } \\
\text { subtraction }\end{array}$ & & $\begin{array}{l}\text { Solve the problems of } \\
\text { everyday life related to the } \\
\text { addition and subtraction of } \\
\text { numbers involving counts up } \\
\text { to } 99\end{array}$ \\
\hline $\begin{array}{l}3.5 \text { Get to know the number } \\
\text { patterns associated with a } \\
\text { collection of objects/ } \\
\text { images/movements or Others }\end{array}$ & 4.5 & $\begin{array}{l}\text { Predict and create number } \\
\text { patterns related to a collection } \\
\text { of objects/ } \\
\text { images/movements or other }\end{array}$ \\
\hline
\end{tabular}

\begin{tabular}{|c|c|c|c|}
\hline \multicolumn{4}{|c|}{ 2nd Grade } \\
\hline \multicolumn{2}{|r|}{ Basic Competence (Knowledge) } & \multicolumn{2}{|c|}{ Basic Competency (Skill) } \\
\hline & $\begin{array}{l}\text { Explain the meaning of the } \\
\text { number and determine the } \\
\text { symbol based on the value of } \\
\text { the place using a concrete } \\
\text { model and how to read it }\end{array}$ & 4.1 & $\begin{array}{l}\text { Read and present the chunk } \\
\text { number and symbol based on } \\
\text { the place value using a } \\
\text { concrete model }\end{array}$ \\
\hline & $\begin{array}{l}\text { Comparing two chunk } \\
\text { numbers }\end{array}$ & 4.2 & $\begin{array}{l}\text { Sort numbers from the } \\
\text { smallest number to the largest } \\
\text { number or vice versa }\end{array}$ \\
\hline & $\begin{array}{l}\text { Explain and do addition and } \\
\text { subtraction of numbers } \\
\text { involving number up to } 999 \text { in } \\
\text { daily life and linking addition } \\
\text { and subtraction }\end{array}$ & 4.3 & $\begin{array}{l}\text { Solve the problem addition } \\
\text { and subtraction of numbers } \\
\text { involving numbers up to } 999 \\
\text { in daily life and linking } \\
\text { addition and subtraction. }\end{array}$ \\
\hline & $\begin{array}{l}\text { Explain multiplication and } \\
\text { division involving chopped } \\
\text { numbers with up to } 100 \text { times } \\
\text { in daily life and link } \\
\text { multiplication and division }\end{array}$ & 4.4 & $\begin{array}{l}\text { Resolve multiplication and } \\
\text { division problems involving } \\
\text { chopped numbers with up to } \\
100 \text { times in daily life and } \\
\text { linking multiplication and } \\
\text { division }\end{array}$ \\
\hline & $\begin{array}{l}\text { Explain the value and equality } \\
\text { of currency fractions }\end{array}$ & 4.5 & 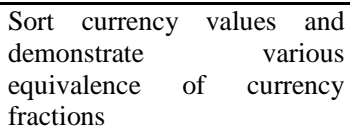 \\
\hline & $\begin{array}{l}\text { Explain fractions } 1 / 2,1 / 3 \text {, and } \\
1 / 4 \text { use concrete objects in } \\
\text { everyday life }\end{array}$ & 4.7 & $\begin{array}{l}\text { Presenting fractions } 1 / 2,1 / 3 \text {, } \\
\text { and } 1 / 4 \text { corresponding with a } \\
\text { part of the overall concrete } \\
\text { objects in everyday life }\end{array}$ \\
\hline \multicolumn{4}{|c|}{ 3rd Grade } \\
\hline \multicolumn{2}{|r|}{ Basic Competence (Knowledge) } & \multicolumn{2}{|c|}{ Basic Competence (Skill) } \\
\hline & $\begin{array}{l}\text { Explain the nature of the } \\
\text { operation count on the number } \\
\text { of the count }\end{array}$ & 4.1 & $\begin{array}{l}\text { Resolve a problem that } \\
\text { involves using the properties } \\
\text { of the calculated operation at } \\
\text { the number of the count }\end{array}$ \\
\hline & $\begin{array}{l}\text { Explaining the count numbers } \\
\text { and simple fractions (such as } \\
1 / 2,1 / 3 \text {, and } 1 / 4 \text { ) which was } \\
\text { served on the number line }\end{array}$ & 4.2 & $\begin{array}{l}\text { Using the count numbers and } \\
\text { simple fractions (such as } 1 / 2 \text {, } \\
1 / 3 \text {, and } 1 / 4 \text { ) which was } \\
\text { served on the number line }\end{array}$ \\
\hline & $\begin{array}{l}\text { Declare a number as the } \\
\text { number, difference, yield, or } \\
\text { result for the two numbers }\end{array}$ & 4.3 & $\begin{array}{l}\text { Assess whether a number can } \\
\text { be expressed as the number, } \\
\text { difference, yield, or outcome } \\
\text { for two chunk numbers }\end{array}$ \\
\hline & $\begin{array}{l}\text { Generalize fraction ideas as } \\
\text { part of the whole using } \\
\text { concrete objects }\end{array}$ & 4.4 & $\begin{array}{l}\text { Presenting fractions as part of } \\
\text { the whole using concrete } \\
\text { objects }\end{array}$ \\
\hline & $\begin{array}{l}\text { Explain and summarize and } \\
\text { subtract the same denominated } \\
\text { fractions }\end{array}$ & 4.5 & $\begin{array}{l}\text { Resolve the sum and } \\
\text { subtraction problem of the } \\
\text { same denomination }\end{array}$ \\
\hline \multicolumn{4}{|c|}{ 4th Grade } \\
\hline \multicolumn{2}{|r|}{ Basic Competence (Knowledge) } & \multicolumn{2}{|r|}{ Basic Competency (Skill) } \\
\hline & $\begin{array}{l}\text { Explain valuable fractions } \\
\text { with concrete images and } \\
\text { models }\end{array}$ & 4.1 & $\begin{array}{l}\text { Identifying } \\
\text { value with concrete images } \\
\text { and models }\end{array}$ \\
\hline & $\begin{array}{l}\text { Describe various forms of } \\
\text { fractions (ordinary, mixed, } \\
\text { decimal, and percent) and the } \\
\text { relationships between them }\end{array}$ & 4.2 & $\begin{array}{l}\text { Identifies various fractional } \\
\text { forms (ordinary, mixed, } \\
\text { decimal, and percent) and the } \\
\text { relationships between them }\end{array}$ \\
\hline & $\begin{array}{l}\text { Explain and assess the } \\
\text { number, difference, results, } \\
\text { and results for two chunks and } \\
\text { fractions and decimals }\end{array}$ & 4.3 & $\begin{array}{l}\text { Resolve the estimation } \\
\text { problem of the number, } \\
\text { difference, results, and results } \\
\text { for two chunks and fractions } \\
\text { and decimals }\end{array}$ \\
\hline & $\begin{array}{l}\text { Explain the factors and } \\
\text { multiples of a number }\end{array}$ & 4.4 & $\begin{array}{l}\text { Identify factors and multiples } \\
\text { of a number }\end{array}$ \\
\hline & Explain prime numbers & 4.5 & Identify prime numbers \\
\hline & $\begin{array}{l}\text { Explain and determine the } \\
\text { factors of fellowship, the } \\
\text { biggest alliance factor (FPB), } \\
\text { multiples of fellowship, and } \\
\text { the smallest multiplication of } \\
\text { alliances (KPK) of two } \\
\text { numbers relating to daily life }\end{array}$ & 4.6 & $\begin{array}{l}\text { Resolve problems related to } \\
\text { partnership factors, the } \\
\text { biggest fellowship factor } \\
\text { (FPB), multiples of alliances, } \\
\text { and the smallest alliance } \\
\text { multiples (KPK) of two } \\
\text { numbers relating to daily life }\end{array}$ \\
\hline
\end{tabular}




\begin{tabular}{|c|c|c|}
\hline \multicolumn{3}{|c|}{ 5th Grade } \\
\hline Basic Competence (Knowledge) & & Basic Competency (Skill) \\
\hline $\begin{array}{l}\text { 3.1 Explain and summarize and } \\
\text { subtract two fractions with } \\
\text { different denominators }\end{array}$ & & $\begin{array}{l}\text { Resolve problems related to } \\
\text { addition and subtraction of } \\
\text { two fractions with different } \\
\text { denominators }\end{array}$ \\
\hline $\begin{array}{l}3.2 \text { Explain and do multiplication } \\
\text { and division of fractions and } \\
\text { decimals }\end{array}$ & & $\begin{array}{l}\text { Resolve problems related to } \\
\text { multiplication and division of } \\
\text { fractions and decimals }\end{array}$ \\
\hline \multicolumn{3}{|c|}{ 6th Grade } \\
\hline Basic Competence (Knowledge) & & Basic Competency (Skill) \\
\hline $\begin{array}{l}\text { 3.1 } \begin{array}{l}\text { Describes negative integers } \\
\text { (including using number lines) }\end{array}\end{array}$ & 4.1 & $\begin{array}{l}\text { Using the concept of negative } \\
\text { integers (including using } \\
\text { number lines) to express } \\
\text { everyday situations }\end{array}$ \\
\hline $\begin{array}{l}\text { 3.2 Explain and perform addition, } \\
\text { subtraction, multiplication and } \\
\text { division operations involving } \\
\text { negative integers }\end{array}$ & & $\begin{array}{l}\text { Resolve problems related to } \\
\text { addition, subtraction, } \\
\text { multiplication, and division } \\
\text { operations involving negative } \\
\text { integers in daily life }\end{array}$ \\
\hline $\begin{array}{l}3.3 \text { Explain and perform mixed } \\
\text { count operations that involve } \\
\text { chopping numbers, fractions } \\
\text { and/or decimals in various } \\
\text { forms according to the } \\
\text { sequence of operations }\end{array}$ & & $\begin{array}{l}\text { Resolve problems related to } \\
\text { mixed counting operations } \\
\text { involving chunks, fractions } \\
\text { and/or decimals in various } \\
\text { forms in the order of } \\
\text { operations }\end{array}$ \\
\hline
\end{tabular}

Based on the basic competency for the scope of numbers that the numbers in the 2013 curriculum are spread from grades 1-6, it can be seen that numbers are so important. In addition, it can be seen that numbers have a strategic position in the 2013 curriculum, so the number sense of elementary school students needs to be developed.

\section{Alternative LeARNING to InCREASE NUMBER SENSE ABILITY}

The number sense ability cannot develop well if it is not excavated, trained, and developed. This is in line with the opinion of Fosnot [14] that number sense skills (number sense) can be taught. Teachers can design learning using a constructivism approach or discovery approach according to the many studies on these two approaches to develop the number sense ability [15]. Therefore on this occasion, will be discussed about alternative learning to develop the ability of student number sense, namely RME ( Realistic Mathematics Education) or PMRI (Indonesian Realistic Mathematics Learning).

PMRI is the result of the adoption of the RME that is considered to be in accordance with Indonesian culture and the characteristics of learning are believed to contribute significantly. PMRI or RME is learning that the starting point of things - things real or experienced s a student, emphasize process skills to argue with your friends so they can find itself (student centered), finally use that math for solving the problem well individuals and groups within their daily lives [16]. Based on the above opinion, PMRI is very suitable for developing the number sense ability, this is because the PMRI learning process focuses on the discovery of concepts by students or also called constructivism.

According to Gravemeijer [17] in mathematics learning using the RME approach, there are three main principles: Guided reinvention and progressive mathematization (Progressive mathematization), didactic phenomenology (didactical phenomenology), and develop models (selfdeveloped model). Based on these three principles, the principle in implementing PMRI is a learning process involving students to rediscover mathematical concepts with activities and problems from the real world that are close to students' lives. Of course, in solving the problem starts with a situation that is close to the life of the student, in the end, it is expected that the formal form of mathematics will begin to form.

In addition to the three principles must be considered in the implementation of PMRI learning, there are also five characteristics of PMRI that must be considered. The five characteristics of PMRI are: using context and contextual, using models, using students' own work and construction, interactive learning processes, and linkages between various topics [18]. Based on the first characteristics, it can be seen that PMRI in implementing learning must use context so that the scope of problems that students will solve is clear and more focused. In addition, the problems presented must also be contextual to bridge the understanding of a concept or algorithm in mathematics.

The second characteristic is using the model, the model serves as a bridge for students' understanding towards formal knowledge. The role of the teacher here is directing, guiding and motivating students to be able to make a model of something problem. The third characteristic, utilizing students' work and construction that can be obtained from various doing mathematics activities. Contribution great at teaching and learning process is expected from the contribution of the students themselves who steer them from informal methods to a more formal or standardized. The fourth and fifth characteristics are the need for interactive learning and there are linkages between various topics. With the interaction and relevance of the topic in the implementation of learning, the classroom atmosphere becomes lively and dynamic.

Considering the five characteristics of PMRI, it can be seen that the implementation of PMRI learning can develop the ability of student number sense due to the contextual learning process, discovery, student-centered, and constructivism-based. This is in line with Pilmer's opinion [15] that constructivism approaches or discovery approaches are suitable for developing number sense capabilities.

The implementation of PMRI learning can be used as an alternative to developing number sense can be seen from several existing research results. Edo et al [19] research results found that with the PMRI approach students have a sense of the magnitude of numbers in which they can compare more with fewer. In addition, students have also been involved in activities that make them aware of the causal relationship between addition and subtraction or addition and subtraction of Cooperatives o opposites. In addition, Sa'dijah [14] found that the average student who initially had a sensitivity of numbers with good enough criteria to be very good through contextual learning, in this case, using PMRI was that originally had a sensitivity of less become number criteria good. This is in line with the results of Mulyanto's [20] research that the RME approach effectively increases the ability to understand the operation of negative integers on mathematics learning in class IV SDN Sukalerang I District Cimalaka District Sumedang. This means that RME can increase the number sense ability. Based on the results of the above research that are relevant to PMRI research and the number of students' sense that has been carried out and has proven its effectiveness, it can be 
said that PMRI has an important position in number sense so that it can be used as an alternative to developing the number sense ability of students.

\section{CONCLUSION}

Based on the description above, it can be seen that the number sense has a lot of benefits, both in mathematics learning in formal education and in daily activities, so it needs attention of all parties, especially teachers, to continue to train and develop number sense by developing effective learning based on constructivism so the concept gained becomes more meaningful. For researchers can be a concern to explore issues related to number sense, as an effective medium of learning, assessment to determine the number sense, learning to develop the abilities number sense, and also looking for solutions to improve number sense in students.

\section{REFERENCE}

[1] Yuniawatika. 2011. Penerapan Pembelajaran Matematika dengan Strategi React untuk Meningkatkan Kemampuan Koneksi dan Representasi Matematika Siswa Sekolah Dasar. (Online), (http://jurnal.upi.edu/file/10-Yuniawatika-edit.pdf), accessed at 26 August 2018.

[2] Walle, John A Van de. 2008. Matematika Sekolah Dasar dan Menengah Edisi Keenam (Jilid 1). Terjemahan Suyono. Jakarta: Erlangga. 2007.

[3] Mullis, Ina V.S. 2015. TIMSS 2015 Assessment Framework. United State: TIMSS \& PIRLS International Study Center, Lynch School of Education, Boston College and International Association for the Evaluation of Educational Achievement (IEA).

[4] NCTM. 2000. Principles and Standards for School Mathematics. Reston. VA: NCTM

[5] Saleh, A. 2009. Number Sense Belajar Matematika Selezat Cokelat. Bandung: Trans Media Pustaka.

[6] Putrawangsa, S. 2018. Strategi dan Tingkat Kepekaan Bilangan Siswa Sekolah Dasar dalam Menyelesaikan Masalah Operasi Bilangan Bulat, Jurnal Pendidikan Matematika Volume 12 (1). (Online) https://www.researchgate.net/profile/Susilahudin_Putrawangsa/public ation/324219207_STRATEGI_DAN_TINGKAT_KEPEKAAN_BIL ANGAN SISWA_SEKOLAH_DASAR_DALAM_MENYELESAIK AN_MASALAH_OPERASI_BILANGAN_BULAT/links/5ac5a396a ca2720544cf8d90/STRATEGI-DAN-TINGKAT-KEPEKAAN-

BILANGAN-SISWA-SEKOLAH -DASAR-DALAMMENYELESAIKAN-MASALAH-OPERASI-BILANGANBULAT.pdf.

[7] Sari, Nur Farida Mala. 2014. Number Sense Siswa Sekolah Dasar (SD) Dalam Menyelesaikan Soal Matematika Ditinjau Dari Kemampuan Matematika. Jurnal MATHEdunesa: Vol.3 No.3. (Online)

(http://jurnalmahasiswa.unesa.ac.id/index.php/mathedunesa/article/vie w/12841), accessed at 3 September 2018).

[8] Safitri, A. S., Mulyati, S., \& Chandra, T. D. (2017, July). Kemampuan Number Sense Siswa Sekolah Menengah Pertama (SMP) Kelas VII pada Materi Bilangan. In Prosiding SI MaNIs (Seminar Nasional Integrasi Matematika dan Nilai-Nilai Islami) (Vol. 1, No. 1, pp. 270-277). http://conferences.uinmalang.ac.id/index.php/SIMANIS. Accessed at 3 September 2018. (Online).

[9] Rahmawati. 2016. Hasil TIMSS 2015. (Online) https://puspendik.kemdikbud.go.id/seminar/upload/Hasil\%20Seminar \%20Puspendik\%202016/Rahmawati-
Seminar\%20Hasil\%20TIMSS\%202015.pdf.

Accessed at 2 September 2018.

[10] Yang, Der-Ching, Robert E. Reys, \& Barbara J. Reys. 2007. Number Sense Strategies Used by Pre-service Teachers in Taiwan. International Journal of Science and Mathematics Education, (7), 383403. (Online), (https://link.springer.com/article/10.1007/s10763-0079124-5), accessed on 2 September 2018.

[11] Mohammed, Mohini \& Johny, Jacinta. 2010. Investigating Number Sense Among Students. I International Conference on Mathematics Education Research 2010 (ICMER2010). https://ac.elscdn.com/S187704281002149X/1-s2.0-S187704281002149Xmain.pdf?_tid=e1aeb8d2-954f-4a0b-85bdfaec84274e0b\&acdnat $=1536013671 \_$be5b6373a67547833b86040a64 $7648 \mathrm{~d} 3$. accessed at 1 September 2018.

[12] Authary, Nailul. 2016. Number Sense Anak Usia Dini: Suatu Investigasi Pada Aritmetika Tahap Awal. Jurnal Ar-Raniry, Volume I No.2. https://jurnal.arraniry.ac.id/index.php/bunayya/article/download/2031/1503), accessed at 2 September 2018.

[13] Tonra, Syam Wildan. 2016. Pembelajaran Number Sense untuk Meningkatkan Hasil Belajar Siswa Sekolah Dasar pada Materi Pecahan. Jurnal Ilmu Pendidikan, (Online). (ejournal.unkhair.ac.id/index.php/deltapi/article/download/233/182). Accessed at 30 August 2018.

[14] Sa'dijah, Cholis. 2013. Kepekaan Bilangan Siswa SMP Melalui Pembelajaran Matematika Kontekstual yang Mengintegrasikan Keterampilan Berpikir Kreatif. Jurnal Pendidikan dan Pembelajaran, Volume 20, Nomor 2, Oktober 2013. http://journal.um.ac.id/index.php/pendidikan-danpembelajaran/article/viewFile/4399/907. (Online) Accessed at 2 September 2018.

[15] Pilmer, David. 2008. Number Sense. Nova Scotia School for Adult Learning. Department of Labour and Workforce Development. https://www.literacyns.ca/docs/NumberSense.pdf. (Online) Accessed at 2 September 2018.

[16] Yuniawatika, Y., Yuspriyati, D. N., Sani, I., \& Febriyanti, F. 2018. Perkembangan Pendidikan Matematika Realistik Indonesia (Pmri) di Lptk Bandung Raya. Mosharafa: Jurnal Pendidikan Matematika, 5(3), 233-246. https://journal.institutpendidikan.ac.id/index.php/mosharafa/article/vi ewFile/mv5n3_6/284.

[17] Dhoruri, Atmini. 2010. Pembelajaran Matematika dengan Pendekatan Matematika Realistik (PMR). http://staff.uny.ac.id/sites/default/files/tmp/Makalah\%20PMRI\%2020 10.pdf. Accessed at 2 September 2018

[18] Zulkardi. 2001. Realistic Mathematic Education (RME) Teori, Contoh Pembelajaran dan Taman Belajar di Internet. Makalah Pada Seminar Sehari Realistic Mathematics Education di Jurusan Pendididkan Matematika UPI. Bandung.

[19] Edo, S. I., Tanghamap, K., \& Tasik, W. F. 2015. Model Pembelajaran Penjumlahan Dan Pengurangan Bilangan Melalui Pendekatan Pmri Konteks Permainan Karet Gelang. Jurnal Pendidikan Matematika, 9(2), 99-123. https://ejournal.unsri.ac.id/index.php/jpm/article/view/2428.

[20] Mulyanto, Respaty. 2007. Pendekatan RME untuk Meningkatkan Pemahaman Operasi Pengurangan Bilangan Bulat Negatif Pada Pembelajaran Matematika di SDN Sukalerang I Kabupaten Sumedang. Jurnal Pendidikan Dasar No 8. http://103.23.244.11/Direktori/JURNAL/PENDIDIKAN_DASAR/No mor_8-

Oktober_2007/Pendekatan_RME_untuk_Meningkatkan_Pemahaman _Operasi_Pengurangan_Bilangan_Bulat_Negatif_Pada_Pembelajaran _Matematika_di_SDN_Sukalerang_I_Kabupaten_Sumedang.pdf. 